\title{
Post-GPI Attachment to Proteins Factor 3
}

National Cancer Institute

\section{Source}

National Cancer Institute. Post-GPI Attachment to Proteins Factor 3. NCI Thesaurus.

Code C150293.

Post-GPI attachment to proteins factor 3 (320 aa, $36 \mathrm{kDa}$ ) is encoded by the human PGAP3 gene. This protein is involved in the maturation of glycophosphoinositol anchoring lipids. 